\title{
The Effects of Using Liposomal Bupivacaine and Aloe Vera Cream after Haemorrhoidectomy on Postoperative Pain, Need for Analgesics, Hospitalisation Period and Return to Work and Social Life
}

\author{
Hemoroidektomi Sonrası Lipozom Bupivacain ve Aleo Vera Krem \\ Kullanımının Postoperatif Ağrıya, Analjezik İhtiyacına, Hospitalizasyon \\ Süresine, İş ve Sosyal Yaşama Dönüşe Etkisi
}

\author{
(D) Murat Kanlıöz1, (D) Uğur Ekici2 \\ ${ }^{1}$ Çankaya University, Ankara, Turkey \\ 2'istanbul Gelişim University, İstanbul, Turkey
}

\section{HIIIIII| ABSTRACT}

Aim: Post-haemorrhoidectomy pain adversely affects the patients' comfort, length of hospitalisation and return to work/school and social life. We investigated the effect of liposomal bupivacaine (LB) and aloe vera $2 \%$ cream (AVC) on post-haemorrhoidectomy pain and wound healing.

Method: We established four treatment groups: G1, G2, G3 and G4. Then, we applied perianal submucosal 300 mg LB to 20 patients in G1 intraoperatively; perianal $300 \mathrm{mg}$ LB + local AVC to 20 patients in G2, 3 times a day, postoperatively; perianal AVC to 20 patients in G3 3 times a day, postoperatively and perianal placebo cream to 32 patients in G4 3 times a day, postoperatively. Patients' pain at rest at the $12^{\text {th }}, 24^{\text {th }}$ and $36^{\text {th }}$ hours and the during defaecation at the $36^{\text {th }}$ hour were scored using the visual analogue scale, "0" indicating "no pain" and "10" indicating "unbearable pain". We recorded their needs for narcotic analgesics within postoperative 12 and 24 hours and for NSAID within 36 hours, as well as their return to social life and work and full recovery periods.

Results: The difference was significant between the following groups: G1-G4 ( $\mathrm{p}=0.042) \& \mathrm{G} 2-\mathrm{G} 4$ ( $\mathrm{p}=0.002$ ) in the need for narcotic analgesics within the first 24 hours, G2-G4 ( $\mathrm{p}=0.002)$ in pain score at the $12^{\text {th }}$ hour, G2-G4 ( $\left.<<0.001\right)$ in pain score at the $24^{\text {th }}$ hour, G2-G4 (p<0.001) \& G3-G4 $(\mathrm{p}=0.001)$ in pain score at the $36^{\text {th }}$ hour, G2-G4 $(\mathrm{p}<0.001)$ in pain score during defaecation at the $36^{\text {th }}$ hour and $\mathrm{G} 2-\mathrm{G} 4$ ( $\left.<<0.001\right)$ in the return to work and social life.

Conclusion: We recommend the combined use of LB and AVC after haemorrhoidectomy.

Keywords: Haemorrhoidectomy, liposomal bupivacaine, aloe vera cream, pain, return to work, need for analgesics

\section{|l||||||| ÖZ}

Amaç: Hemoroidektomi sonrası ağrı, hastanın konforunu, hastanede kalış süresini, işe, okula ve sosyal hayata dönüşünü belirleyen en önemli etkendir. Lipozom bupivacain (LB) ve aleo vera \%2 kremin (AVC) hemoroidektomi sonrası ağrı ve yara iyileşmesindeki etkinliğini araştırdık.

Yöntem: G1, G2, G3 ve G4 adı altında dört farklı tedavi grubu oluşturuldu. Ligasure cihazı ile hemoroidektomi yapılan hastalardan Gl'deki 20 hastaya intraoperatif perianal submukozal 300 mg LB, G2'deki 20 hastaya 300 mg LB (+) anal bölgeye postoperatif günde üç kez lokal AVC, G3'teki 20 hastaya postoperatif anal bölgeye günde üç kez AVC, G4'teki 32 hastaya postoperatif günde üç kez anal bölgeye plasebo krem uygulandı. Hastaların 12,24 ve 36. saatteki istirahat ve de 36. saatteki defekasyon esnasındaki ağrıları visuel analog skalaya göre ağrısı yoksa "0", dayanılmaz ağrısı var ise "10" puan olacak şekilde skorlandı. Postoperatif 12 ve 24 saat içerisindeki narkotik analjezik ihtiyaçları, 36 saat içerisindeki NSAIDD ihtiyaçları, sosyal hayata ve işe geri dönüş süreleri ile tam iyileşme zamanları kaydedildi. 
Bulgular: İlk 24 saatteki narkotik analjezik ihtiyacı açısından G1-G4 ( $p=0,042), G 2-G 4$ ( $p=0,002)$, 12. saatteki ağrı skoru açısından G2-G4 (p=0,002), 24. Saatteki ağrı skoru açısından G2-G4 (p<0,001), 36. saat istirahat ağrı skoru açısından G2-G4 (p<0,001) ve G3-G4 (p=0,001), 36. saat defekasyon esnası ağrı skoru açısından G2-G4 ( $\mathrm{p}<0,001)$, iş ve sosyal hayata dönüş açısından $G 2-G 4$ ( $\mathrm{p}<0,001)$ arasındaki farklar anlamlıydı.

Sonuç: Hemoroidektomi sonrasında LB ve AVC'nin birlikte kullanılmasını öneriyoruz.

Anahtar Kelimeler: Hemoroidektomi, lipozom bupvacain, aleo vera krem, ağrı, işe dönüş, analjezik ihtiyacı

\section{Introduction}

Haemorrhoids are natural structures of the anal canal that consist of vascular tissues, loose connective tissues, muscle tissues (Treitz muscle) and vascular connections within the submucosal layer. ${ }^{1}$ They are considered essential because they ensure continence by acting as fibrovascular pillows. Haemorrhoids above the dentate line are called "internal haemorrhoids" and those below are called "external haemorrhoids". Haemorrhoidal diseases occur when haemorrhoids are symptomatic. External haemorrhoids are fed by the inferior haemorrhoidal artery, whereas the internal ones are fed by the superior haemorrhoidal artery. External and internal haemorrhoids are drained through the systemic circulation via the inferior haemorrhoidal vein and the portal system via the superior haemorrhoidal vein, respectively. As such, they create the portosystemic junction region. ${ }^{2}$ Although the literature on the incidence of haemorrhoidal disease presents rates from 4 to $40 \%, 75 \%$ of individuals suffer from haemorrhoidal diseases at some point in their lives. ${ }^{3}$ The treatment methods of haemorrhoidal diseases can be divided into two groups: medical and surgical treatments. However, we recommend that conservative therapies be used in the first step. ${ }^{4}$ The use of Ligasure in surgical treatment relieved the complaints of the patients in the postoperative perio. ${ }^{5}$ Even though postoperative complaints can be decreased with the Ligasure treatment, pain and bleeding still persist as important problems. The pain experienced after haemorrhoidectomy lengthens the hospital stay, increases the need for additional analgesics and prolongs the return to social life and work. Our study investigated the effects of intraoperative, local, perianal and submucosal liposomal bupivacaine (LB) injection and aloe vera $2 \%$ cream (AVC) use in relieving the postoperative complaints of patients who undergo haemorrhoidectomy with Ligasure.

\section{Materials and Methods}

After informing the patients who were to undergo the haemorrhoidectomy procedure of the present study and treatment methods, and explaining that participating (or not) in the study would not cause any disruption in their treatment, the written and oral consents of the volunteer participants were obtained and they were included in the study. Then, we established four randomised treatment groups from the patients who underwent haemorrhoidectomy with the Ligasure device. Patients were assigned to the treatment groups by a simple probability randomisation method. We applied intraoperative, local, perianal, submucosal $300 \mathrm{mg}$ LB injections to the group 1 (G1) patients; intraoperative, local, submucosal $300 \mathrm{mg} \mathrm{LB}$ injections \& $1 \mathrm{~cm}^{3}$ of local AVC in the perianal skin three times a day, postoperatively, to the group 2 (G2) patients; $1 \mathrm{~cm}^{3}$ of local AVC in the perianal skin three times a day, postoperatively, to the group 3 (G3) patients; and $1 \mathrm{~cm}^{3}$ of local placebo cream in the perianal skin three times a day, postoperatively, to group 4 (G4) patients. We then asked patients to score their pain between "0" and "10", "0" indicating "no pain" and "10" indicating "unbearable pain", according to the visual analog scale (VAS). The patients scored their pain at rest at the $12^{\text {th }}, 24^{\text {th }}$ and $36^{\text {th }}$ hours and pain during defaecation at the $36^{\text {th }}$ hour in the postoperative period according to the VAS. Then, we asked questions on the following points to the patients and recorded their answers: Need (mg) for peptidin $\mathrm{HCl}$ (Aldolan ${ }^{\mathrm{TM}}$ ) due to pain within postoperative 12 and 24 hours, amount (mg) of Dexketoprofen Trometamol (Arveles ${ }^{\mathrm{TM}}$ ) used in the first postoperative 36 hours, postoperative hospital stay (hours), postoperative return to social life (days), postoperative return to work (days), the day of full recovery in the postoperative period (the day when the postoperative complaints completely disappeared).

\section{Statistical Analysis}

Discrete numerical data were expressed as median (minimum-maximum) values, while continuous numerical data were expressed as mean \pm standard deviation. To analyse the normal distributions of the groups, we used Shapiro-Wilks test. However, we used the Kruskal-Wallis test since their distribution was not normal, and used the one-way ANOVA test for multiple comparisons of the groups. The categorical data were expressed in numbers (percentages). In all the tests, a p value less than 0.05 was considered significant. All the analyses were done using IBM SPSS Statistics for Windows version 25.0.

\section{Results}

A total of 92 patients were included in this study, including 20 each in G1, G2 and G3 and 32 in G4. The mean age of the patients was $37.13 \pm 12.68$ years. Of the patients, $32(34.8 \%)$ were females and 60 (65.2\%) were males (Table 1). 
In the first postoperative 12 hours, there was no difference between the groups in terms of the need for the analgesic "peptidin HCl" (Table 2). However, a significant difference was found between G1 and G4 ( $p=0.042)$ and G2 and G4 ( $\mathrm{p}=0.002)$ in terms of the need for "peptidin $\mathrm{HCl}$ " in the first 24-hour period (Table 2).

According to the VAS, we found significant differences in terms of pain scores between G2 and G4 $(\mathrm{p}=0.002)$ at the $12^{\text {th }}$ hour, G2 and G4 ( $\left.<<0.001\right)$ and G3 and G4 ( $\left.=0.006\right)$ at the $24^{\text {th }}$ hour, and G1 and G2 ( $\left.\mathrm{p}=0.008\right), \mathrm{G} 1$ and G4 ( $\mathrm{p}=0.004), G 2$ and G3 (p=0.038), G2 and G4 ( $\mathrm{p}<0.001)$ as well as G3 and G4 (p=0.001) at the $36^{\text {th }}$ hour during rest in the postoperative period (Table 2).

In addition, according to the VAS, there was a significant difference between G2 and G4 $(p<0.001)$ in terms of the pain scores during defaecation at the postoperative $36^{\text {th }}$ hour (Table 2).

Table 1. Number and age of patients according to treatment groups

\begin{tabular}{|c|c|c|c|c|c|}
\hline & \multicolumn{5}{|c|}{ Treatment groups } \\
\hline & G1 & G2 & G3 & G4 & TOTAL \\
\hline \multicolumn{6}{|l|}{ Number of patients $\mathrm{n}(\%)$} \\
\hline Female & $7(35)$ & $9(45)$ & $4(20)$ & $12(37.5)$ & $32(34.8)$ \\
\hline Male & $13(65)$ & $11(55)$ & $16(80)$ & $20(62.5)$ & $60(65.2)$ \\
\hline Total & 20 & 20 & 20 & 32 & 92 \\
\hline \multicolumn{6}{|l|}{ Age of patients (year) } \\
\hline Mean \pm standard deviation & $12.1 \pm 17.00$ & $33.5 \pm 11.43$ & $38.2 \pm 12.27$ & $35.25 \pm 12.07$ & $37.13 \pm 12.68$ \\
\hline Median (min-max) & $43(20-65)$ & $30(19-52)$ & $35(19-63)$ & $34(20-68)$ & $35(19-68)$ \\
\hline
\end{tabular}

min: Minimum, max: Maximum

Table 2. Postoperative analgesic requirements of patients according to treatment groups

\begin{tabular}{|c|c|c|c|c|c|}
\hline & Treatment groups & & & & \\
\hline & $\begin{array}{l}\text { Bupivacain (G1) } \\
\mathrm{n}=20\end{array}$ & $\begin{array}{l}\text { Bupivacain }(+) \\
\text { aleo vera }(G 2) \\
n=20\end{array}$ & $\begin{array}{l}\text { Aleo vera }(G 3) \\
n=20\end{array}$ & $\begin{array}{l}\text { Placebo (G4) } \\
\mathrm{n}=32\end{array}$ & $\mathrm{p}$ \\
\hline $\begin{array}{l}\text { Peptide } \mathrm{HCl} \text { requirement in the first } 12 \\
\text { hours postoperatively } \mathrm{n}(\%)\end{array}$ & & & & & $\begin{array}{l}\text { G1-G2: }=0.99 \\
\text { G1-G3: }=0.42\end{array}$ \\
\hline *No need & $18(90)$ & $19(95)$ & $15(75)$ & $20(62.5)$ & G1-G4: $=0.11$ \\
\hline *25 mg used & $2(10)$ & $1(5)$ & $3(15)$ & $9(28.1)$ & $\mathrm{G} 2-\mathrm{G} 3=0.28$ \\
\hline *50 mg used & $0(0)$ & $0(0)$ & $1(5)$ & $2(6.3)$ & G2-G4: $=0.058$ \\
\hline *Used more than $50 \mathrm{mg}$ & $0(0)$ & $0(0)$ & $1(5)$ & $1(3.1)$ & G3-G4: =0.94 \\
\hline $\begin{array}{l}\text { Peptide } \mathrm{HCl} \text { requirement in the first } 24 \\
\text { hours postoperatively n (\%) }\end{array}$ & & & & & $\begin{array}{l}\text { G1-G2: }=0.821 \\
\text { G1-G3: }=0.745\end{array}$ \\
\hline *No need & $17(85)$ & $19(95)$ & $13(65)$ & $18(56.3)$ & G1-G4: $=0.042 *$ \\
\hline *25 mg used & $2(10)$ & $1(5)$ & $5(25)$ & $5(15.6)$ & G2-G3: =0.119 \\
\hline *50 mg used & $1(5)$ & $0(0)$ & $2(10)$ & $5(15.6)$ & G2-G4: $=0.002 *$ \\
\hline \multirow[t]{2}{*}{ *Used more than $50 \mathrm{mg}$} & $0(0)$ & $0(0)$ & $0(0)$ & $4(12.5)$ & G3-G4: $=0.537$ \\
\hline & & & & & G1-G2: $=0.869$ \\
\hline Postoperative $12^{\text {th }}$ hour resting pain score & & & & & G1-G3: $=0.988$ \\
\hline$*$ Mean \pm standard deviation & $0.8 \pm 1.4$ & $0.4 \pm 0.88$ & $1.1 \pm 1.55$ & $1.75 \pm 1.65$ & G1-G4: $=0.173$ \\
\hline *Median (min-max) & $0(0-4)$ & $0(0-3)$ & $0(0-5)$ & $2(0-6)$ & G2-G3: $=0.431$ \\
\hline *Pain score "0" n (\%) & $14(70)$ & $16(80)$ & $11(55)$ & $10(31.2)$ & G2-G4: $=0.002 *$ \\
\hline & & & & & G3-G4: $=0.645$ \\
\hline
\end{tabular}


Table 2 contiuned

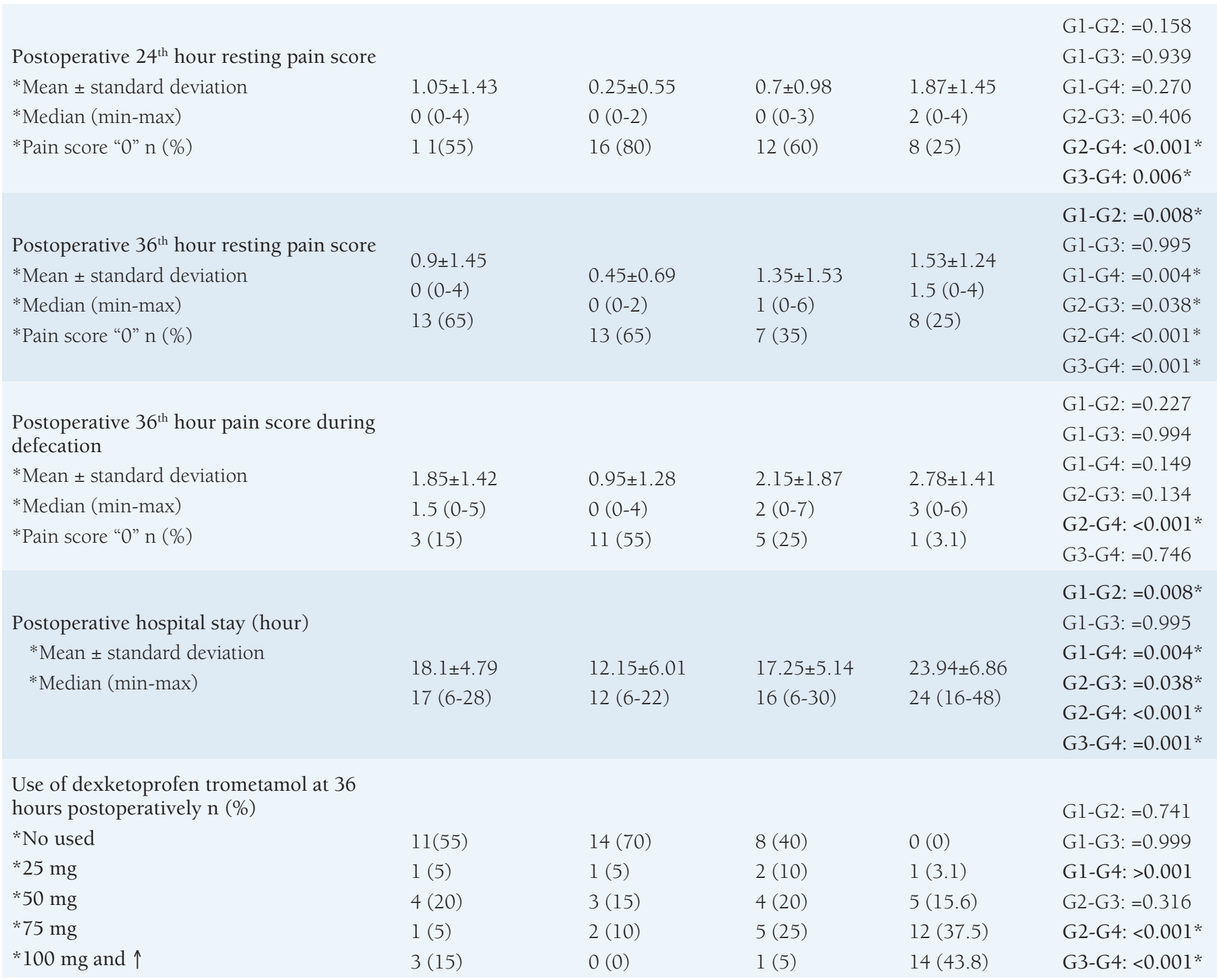

min: Minimum, max: Maximum

The differences between G1 and G2 ( $\mathrm{p}=0.008), \mathrm{Gl}$ and $\mathrm{G} 4$ $(\mathrm{p}=0.004), \mathrm{G} 2$ and $\mathrm{G} 3$ ( $\mathrm{p}=0.038), \mathrm{G} 2$ and $\mathrm{G} 4(\mathrm{p}<0.001)$ and G3 and G4 ( $p=0.001)$ were also significant in terms of the postoperative hospital stay (Table 2 ).

Also, the differences between G1 and G4 ( $\mathrm{p}<0.001$ ), G2 and $G 4(p<0.001)$ and $G 3$ and $G 4(p<0.001)$ were found to be significant with regard to the use of Dexketoprofen Trometamol within the first 36 hours (Table 2).

In terms of the time of return to social life in the postoperative period, the differences between G2 and G4 $(\mathrm{p}<0.001)$ and G3 and G4 ( $<<0.001$ ) were found to be significant (Table 3). Our analysis on the time of return to work in the postoperative period showed significant differences between G1 and G2 $(\mathrm{p}=0.023), \mathrm{G} 2$ and $\mathrm{G} 4(\mathrm{p}<0.001)$ and G3 and G4 $(\mathrm{p}=0.003)$ (Table 3)

In terms of the full recovery in the postoperative period, the differences between $\mathrm{G} 2$ and $\mathrm{G} 4(\mathrm{p}=0.001)$ and $\mathrm{G} 3$ and $\mathrm{G} 4$ $(p<0.001)$ were found to be significant (Table 3 ).

\section{Discussion}

In haemorrhoidectomies, the pain in the wound area, which is one of the most important problems during the first 12 and 24 hours, does not only impair the patient's comfort, but also creates the need for additional analgesia and prolongs the hospital stay. As we analyse the data from the four different groups, we found a significant correlation 
Table 3. Postoperative return to social life, return to work and complete recovery times

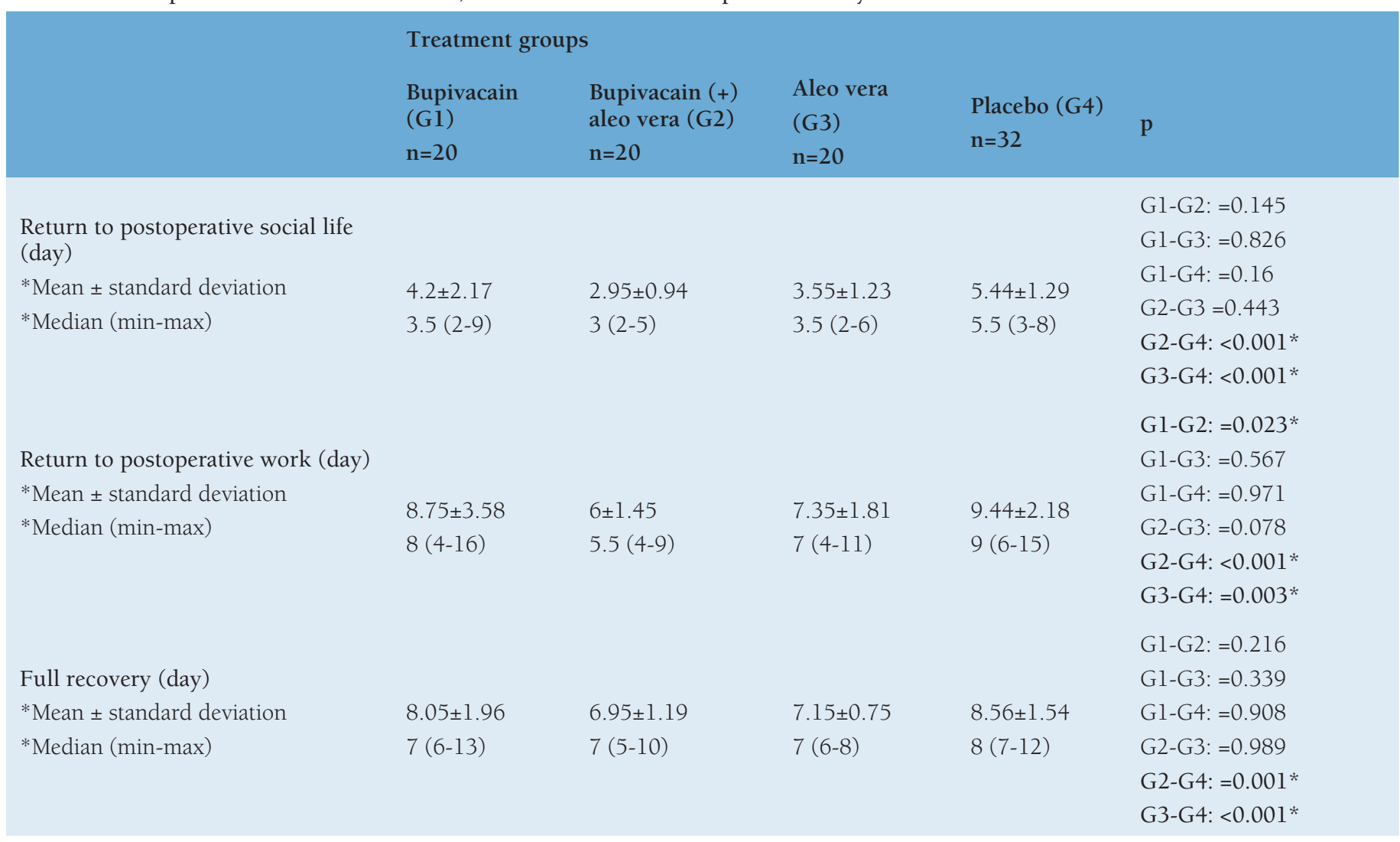

min: Minimum, max: Maximum

between G2 and G4 ( $p<0.001)$ in terms of pain scores at the postoperative $12^{\text {th }}$ hour, and found no significant difference between the groups in terms of the peptidin $\mathrm{HCl}$ used in the postoperative 12-hour period. We also observed that there were significant differences between G2 and G4 ( $<<0.001)$ $\&$ G3 and $\mathrm{G} 4(\mathrm{p}=0.006)$ in terms of pain scores at the postoperative $24^{\text {th }}$ hour, and between G1 and G4 ( $\mathrm{p}=0.042$ ) and $G 2$ and $G 4$ ( $p=0.002$ ) with regard to the need for peptidin HCI within the postoperative 24 hours. In terms of pain score and the need for narcotic analgesics in the first 24 hours, the correlation between G2 and G4 stands out. The combined use of LB and AVC in G2 significantly reduced the need for analgesia and resulted in lower pain scores. In their study, Kwok et al. ${ }^{6}$ reported having performed submucosal Bupivacaine injections during band ligation treatment in haemorrhoids under local anaesthesia. After 15 minutes from the procedure, they asked the patients to score their pain according to the VAS immediately before their discharge from hospital. They noted that the patients reported a lower pain score in the Bupivacaine group compared to the control group. ${ }^{6}$ In another study, Schmidt et al. $^{7}$ reported that patients who received Bupivacaine during haemorrhoidectomy had lower pain scores at the postoperative $12^{\text {th }}$ and $24^{\text {th }}$ hours and they needed less Opioid in the postoperative 72-hour period.

According to the VAS, the differences between G1 and G2 ( $\mathrm{p}=0.008), \mathrm{G} 1$ and $\mathrm{G} 4$ ( $\mathrm{p}=0.004), \mathrm{G} 2$ and $\mathrm{G} 3$ ( $\mathrm{p}=0.038), \mathrm{G} 2$ and G4 $(\mathrm{p}<0.001)$ and G3 and G4 ( $\mathrm{p}=0.001)$ were significant in terms of pain scores at rest at the postoperative $36^{\text {th }}$ hour. Again, according to VAS, there was a significant difference between $G 2$ and $G 4(p<0.001)$ in terms of the pain scores during defaecation at the postoperative $36^{\text {th }}$ hour. Regarding the pain scores at rest in the $36^{\text {th }}$ hour, we observed that the placebo group particularly differed negatively from all the treatment methods. Rajabi et al. ${ }^{8}$ reported that the postoperative need for opioids decreased in patients who received the ischiorectal block treatment with Bupivacaine in haemorrhoidectomies. On the other hand, Eshghi et al. ${ }^{9}$ report that they used aloe vera gel on the anal area for four weeks after haemorrhoidectomy, and as a result thereof, the treatment showed a significant success in pain relief and wound healing after defaecation compared to the control 
group. However, the difference between G2 and G4 stands with regard to the pain during defaecation at the $36^{\text {th }}$ hour. At this point, what puts those groups ahead of the other groups is the effect of the LB \& AVC combination on pain relief. Rahmani et al. ${ }^{10}$ report that they achieved statistically significant differences in the treatment group composed of patients for whom they used aloe vera cream in the treatment of chronic anal fissure with regard to the pain, bleeding and wound healing after defaecation, compared to the control group $(\mathrm{p}<0.05)$.

In all the three treatment groups (G1, G2 and G3), the need for Dexketoprofen Trometamol in the first 36 hours was less than that in the control group (G4). This proves that the need for analgesics could be decreases by applying LB and AVC either alone or in combination. In their multi-centre, randomised, double-blind, placebo-controlled study on haemorrhoidectomies, Gorfine et al. ${ }^{11}$ pointed out that there was a statistically significant reduction in terms of pain scores and the need for opioids within the first 72 hours in the Liposome Bupivacaine group ( $\mathrm{p}<0.05$ ).

All the treatment groups differ positively from the control group in terms of the length of hospital stay. The main factors that affect the length of hospital stay are the pain and the bleeding.

In the healing process after haemorrhoidectomy, the pain level distinguishes itself as the most important determinant for returning to social life, work or school. The time to return to work and social life was shortened, especially when the pain at rest was reduced or completely relieved. In our study, there were significant differences between G2 and G4 and G3 and G4 in terms of the return to both social life and work. It is important to find differences in treatment groups who received the AVC treatment. There was no difference between the control and LB groups, indicating that the main determining effect at this point is AVC. In their study, Prakaso et al. ${ }^{11}$ pointed out that the cream containing $1 \%$ and $2 \%$ aloe vera had a potential of wound healing owing to its ability to increase the proportion of CD4+/CD8+ lymphocytes in the wound area in their animal experiment for topical application of aloe vera. Also, in their study in which, they investigated TGF- $\beta$ gene expression in the wound bed in terms of wound healing on Wistar rats using aloe vera gel. Takzare et al. ${ }^{12}$ concluded that aloe vera proved to be effective in wound healing. In another study, Dat et al. ${ }^{13}$ concluded that aloe vera had no significant effect in chronic wound healing in their meta-analysis on 347 cases. They report that there exist no high-quality clinical trial evidences to support the use of aloe vera topical agents for therapeutic purposes in acute and chronic wounds. ${ }^{13}$

\section{Conclusion}

We cannot address pain, wound healing and painless defaecation separately after haemorrhoid surgeries, since a discomfort caused by any of them would affect the others. All the three treatment methods used in our study contributed, to the comfort of patients in the postoperative period. However, we recommend opting for the combined use of LB and AVC in treatment.

\section{Ethics}

Ethics Committee Approval: This work has been approved by the Institutional.

Informed Consent: Obtained.

Peer-review: Internally and externally peer reviewed.

\section{Authorship Contributions}

Surgical and Medical Practices: M.K., U.E., Concept: M.K., Design: M.K., U.E., Data Collection or Processing: M.K., U.E., Analysis or Interpretation: M.K., U.E., Literature Search: M.K., U.E., Writing: M.K.

Conflict of Interest: No conflict of interest was declared by the authors.

Financial Disclosure: The authors declared that this study received no financial support.

\section{References}

1. London S, Tichauer MB. StatPearls [Internet]. StatPearls Publishing; Treasure Island (FL): Jan 24, 2019. Anoscopy. [PubMed]

2. Godlewski G, Prudhomme M. Embryology and anatomy of the rectum. In: Skandalakis JE, Flament JB, eds. Surgical Anatomy and Embryology, Surg Clin North Am 2000;80:319-348.

3. Mott T, Latimer K, Edwards C. Hemorrhoids: Diagnosis and Treatment Options. Am Fam Physician. 2018;97:172-179.

4. Zagriadskiî EA, Bogomazov AM, Golovko EB. Conservative Treatment of Hemorrhoids: Results of an Observational Multicenter Study. Adv Ther 2018;35:1979-1992.

5. Altomare DF, Milito G, Andreoli R, Arcanà F, Tricomi N, Salafia C, Segre D, Altomare DF, Milito G, Andreoli R, Arcanà F, Tricomi N, Salafia C, Segre D, Pecorella G, Pulvirenti d'Urso A, Cracco N, Giovanardi G, Romano G; Ligasure for Hemorrhoids Study Group. Ligasure Precise vs. conventional diathermy for Milligan-Morgan hemorrhoidectomy: a prospective, randomized, multicenter trial. Dis Colon Rectum 2008;51:514-519.

6. Kwok HC, Noblett SE, Murray NEA, Merrie AEH, Hayes JL, Bissett IP. The use of local anaesthesia in haemorrhoidal banding: a randomized controlled trial. Colorectal Dis 2013;15:487-491.

7. Schmidt WK, Patou G, Joshi GP. Evaluating therapeutic benefit in postsurgical analgesia requires global assessment: an example from liposome bupivacaine in hemorrhoidectomy. Hosp Pract (1995) 2012;40:160-165.

8. Rajabi M, Hosseinpour M, Jalalvand F, Afshar M, Moosavi G, Behdad S. Ischiorectal block with bupivacaine for post hemorrhoidectomy pain. Korean J Pain. 2012;25:89-93.

9. Eshghi F, Hosseinimehr SJ, Rahmani N, Khademloo M, Norozi MS, Hojati O. Effects of Aloe vera cream on posthemorrhoidectomy pain and wound healing: results of a randomized, blind, placebo-control study. J Altern Complement Med 2010;16:647-650. 
10. Rahmani N, Khademloo M, Vosoughi K, Assadpour S. Effects of Aloe vera cream on chronic anal fissure pain, wound healing and hemorrhaging upon defection: a prospective double blind clinical trial. Eur Rev Med Pharmacol Sci 2014;18:1078-1084.

11. Prakoso YA, Kurniasih. The Effects of Aloe vera Cream on the Expression of CD4+ and CD8+ Lymphocytes in Skin Wound Healing. J Trop Med 2018;2018:6218303.
12. Takzaree N, Hadjiakhondi A, Hassanzadeh G, Rouini MR, Manayi A, Zolbin MM. Transforming growth factor- $\beta$ (TGF- $\beta$ ) activation in cutaneous wounds after topical application of aloe vera gel. Can J Physiol Pharmacol 2016;94:1285-1290.

13. Dat AD, Poon F, Pham KBT, Doust J. Aloe vera for treating acute and chronic wounds. Cochrane Database Syst Rev 2012:CD008762. 